CRÍTICA, Revista Hispanoamericana de Filosofia

Vol. XXV, No. 74 (agosto 1993): 105-116

\title{
PERSPECTIVISM AND THE ABSOLUTE CONCEPTION OF THE WORLD
}

KAi NIELSEN

The University of Calgary

Bernard Williams, while rejecting metaphysical realism as thoroughly as Hilary Putnam, Richard Rorty and Jürgen Habermas, rejects as well the localized perspectivism of the former two with its at least alleged relativistic tendencies (tendencies both Rorty and Putnam try to resist). ${ }^{1}$ Williams does this by developing something he has called an "absolute conception" of the world (Williams's scare quotes) which is a conception that abstracts to the maximum degree from the peculiarities of any set of observers. (13) Indeed it is a conception which seeks to escape perspectivism altogether. Williams notes that descriptions of the world vary in the degree to which they are "local, or perspectival or anthropocentric." (13) To say of a forest that it's a spruce forest, that the trees are dark green, that

1 Bernard Williams, "Terrestrial Thoughts, Extraterrestrial Science," London Review of Books (Feb 7, 1991), 12-13. References to this article are given in the text. See also Bernard Williams, Descartes: The Project of Pure Enquiry (Harmondsworth, Middlesex: Penguin Books, 1978), pp. 236-303 and Bernard Williams, Ethics and the Limits of Philosophy (Cambridge, Massachusetts: Harvard University Press, 1985), pp. 135-139. For Putnam on Williams's “absolute conception", see Hilary Putnam, Realism with a Human Face (Cambridge, Massachusetts: Harvard University Press, 1990), pp. 130 167 and Hilary Putnam, Renewing Philosophy (Cambridge, Massachusetts: Harvard University Press, 1992), pp. 80-107, 123. 
the forest is dense, that it is dark, that it is foreboding is to give increasingly more localized and anthropocentric descriptions. Williams's "absolute conception" of the world, which he claims has nothing to do with metaphysical realism ("the view that we can conceive of the world in some way quite independent of our theories and the terms in which we describe it"), is the idea "of an account of the world that would be maximally independent of human peculiarities, the ideal of a description that could be used by any observer, even a non-human one, who was capable of investigating the world." (12) This conception, if intelligible, would give us a view of the world which was not anthropocentrically localized and perspectival.

Putnam and Rorty think that this conception is incoherent, and Williams tries to defend it from their attacks. Williams thinks that Putnam believes it to be incoherent because he thinks it commits one to metaphysical realism. But, Williams claims, it no more so commits one than does Habermas's conception of undistorted discourse. But, by contrast with Habermas, Williams's "absolute conception" is used to try to give sense to the contrast between "the world as it is in itself" and "the world as it seems to us." 2 Williams believes this is a contrast we need in order to explain the ambition of science. Without this contrast we would not capture something that is essential to the selfimage of scientists. It might, of course, be retorted that it is what they do, not their self-images or their meta-beliefs about their activities, that counts. But that point aside for some other occasion, it is certainly at least plausible to think scientists would want to make such a contrast. Most

2 This, Williams's disclaimers to the contrary notwithstanding, sounds suspiciously like metaphysical realism. We are trying to say what the world is like as it is in itself and what is this but to conceive of the world in some way quite independent of our theories and the terms in which we describe it. 
of them, particularly if they are physicists, chemists, biologists, or geologists, think that they are getting at what the world is really like and not at just how it seems to us. Perhaps that is an illusion, perhaps even an incoherency, but it is not implausible to think that it is part of their ambition, one their deepest hopes that fuels their inquiries. Would they, if they were reasonable, want to go on doing science if they did not think so?

However, with a rather Putnamist twist, Williams goes on to remark, after claiming that that is the contrast scientists need, that his own aim, by contrast, "was to explain what we might mean by this contrast, not from outside our conceptions, but in terms of reflections we can conduct within human life, the only place (needless to say) in which we can conduct them." (13) A central issue between Putnam and Williams, as it is between Rorty and Habermas, is whether this notion of an absolute conception, or in Habermas's case, on the surface at least, something like it, makes sense and whether, even if it does make sense, science really requires it. I think the verdict isn't in here yet, though I think many philosophers have an ideological proclivity to believe that it must be the case that science must have such an aim. On the Putnam-Rorty side, to consider only the first issue, there is the argument Putnam deploys against both Williams and metaphysical realists that the world contains no fixed number of objects. Asked whether a grove of trees with ten trees is one object, five, eight, ten, twelve or whatever, there is, Williams agrees with Putnam, no answer. But this, Williams believes, strangely it seems to me, does not at all count against the "absolute conception" but only reminds us, he remarks, of "the exceedingly wellknown point that 'object' is not a concept under which you can count." (13) Still, as in the above example, we can, he continues, correctly say something determinate about the world, namely, that there are ten trees in a certain grove. 
That is not a matter of human devising but of human discovery, though what it is to count as a tree certainly is. But, by contrast, how many objects there are in the world is not. It is a matter neither of devising nor of discovery. To believe that it has an answer, that it asks a genuine question, is to be caught up in an incoherency. Against the very idea that we could discover that the world is a certain determinate way that our vocabulary must simply accommodate, Putnam, along with Donald Davidson, will tell an equally familiar story about the indeterminacy of reference. The idea that we have representations that simply mirror the world is without sense.

However this clash between Williams and Putnam will play itself out, it seems to me that both sides need to preserve intact the following two claims: 1) That "we live in a world that exists independently of us and our thoughts," what Williams calls the banal and uncontroversial sense of realism, a thoroughly commonsense realism. Still such a banality is, plainly, incompatible with all forms of idealism. But the banality is also plainly true, so idealism is at best false. But this does not undermine all forms of irrealism or anti-realism or establish representationalism. 2) The second claim to be preserved is that some descriptions, conceptualizations and perspectives are more localized than others (sometimes so as to even be ethnocentric) and that sometimes, in the interest of greater objectivity and getting a better account of things, it is a good idea to go to the less localized, less ethnocentric, ways of viewing things. This leaves space for Habermas's conception of undistorted discourse, though not for Williams's "absolute conception." Against what the above may suggest, I should add that Habermas's conception of undistorted discourse may not be vulnerable to the worries that beset Williams's "absolute conception." Undistorted discourse does not attempt to escape perspectivism and undistorted 
discourse, as well as distorted discourse, is anthropocentric through and through, but anthropocentricity is one thing, ethnocentricity and parochialism are another. Perspectivism, Williams to the contrary notwithstanding, may be inescapable, but there are wider and narrower perspectives and, what is not at all the same thing, distorted and undistorted perspectives. ${ }^{3}$

We do not understand what it would be like to view things from no perspective or viewpoint at all or to just describe things from no point of view at all, utterly abstracting from all human purposes. ${ }^{4}$ Talk of "The View from Nowhere" or of "The Point of View of the Universe" is incoherent or at the very least the burden is on people who would so speak to show how such talk could make sense. (Something like a via negativia will not do here. We cannot just say what such a viewpoint isn't.) There are, however, plainly wider and narrower perspectives. When, for example, plain people (in Mexico or Canada, for example) speak of marriage or of cousins or nephews and the like, they have a rather narrower perspective, have a more limited range of cases and conceptions in mind, than do social anthropologists when they describe marriage, family and kinship structures. The narrower, more limited perspective will also, in this case, and many like it, be ethnocentric and thereby distorted if it takes the only kind of marriage that there can be to be monogamous marriage or takes the very idea of a family to be identical with our conception of a nuclear family. Similar things obtain with religion. In Christian societies many will think that

3 See here crucially Richard Rorty, "Pragmatism As Anti-Representationalism," Pragmatism from Peirce to Davidson, ed. John P. Murphy, (Boulder, Colorado: Westview Press, 1990), pp. 1-6. This is Rorty's introduction to the book.

4 Indeed to view things from no perspective or viewpoint at all certainly has at least the appearance of a contradiction. 
we cannot have a religion without belief in God and when they come to hear about certain forms of Buddhism (forms with neither God, gods, nor worship), they, not infrequently, will deny that such Buddhism is really a religion and will assert that it is simply a way of life or a cluster of moral practices. Students of comparative religion, by contrast, with a wider and more structurally articulated view of what religion is, will see important features in common between Buddhism and Christianity and classify them both as religions. There have been similar ethnocentric characterizations of "the moral point of view."

So perspectives, depending on our purposes, on how comprehensive we want or need to be, depending on what we know or are in a position to know, can be wider or narrower. But they can also be ethnocentric and distorted, as were the narrower conceptions about what marriage, family, religion or morality is — "really is" - mentioned above. But the narrower perspectives need not be ethnocentric or distorted, as they sometimes are not, when they are invoked for certain clearly articulated, circumscribed and non-partisan purposes, as when John Rawls limits his conceptualization of political justice to constitutional democracies under conditions of moderate scarcity. He is concerned to set out a conception of political justice for such societies without at all denying that other types of society could have just political institutions or that it makes sense to speak of global justice. Rawls just narrows his perspective for certain clearly expressed and arguably defendable purposes. He conceptualizes political justice narrowly, but it does not follow from that that his conceptualization is ethnocentric or distorted.

Narrower perspectives, as I mentioned, are, the above notwithstanding, likely to be distorted - they are prone to distortion - but they need not be and wide perspectives can also be distorted. In speaking of a perspective 
as undistorted, we are giving to understand that a) it is clearly articulated, b) it does not utilize incoherent conceptions, c) its premises are good candidates for being true or otherwise warrantable, d) it is free of inductive and deductive errors, and e) is generated and sustained in a certain way. By e) I mean that it is created, and continues to operate, under conditions of freedom and equality and that it would gain the unforced acceptance of all normally rational people with the relevant interests and purposes, where the only constraints on their acceptance, their distinctive interests and purposes aside, would be the force of the better argument or the more adequate deliberation. ${ }^{5}$

5 Keep firmly in mind here that being distorted and being undistorted are things that admit of degree. Things can be more or less distorted in a way, on my conception, they cannot be more or less anthropocentric. I am - to help show how an absolute conception of the world is incoherent - here regimenting language a bit. There are uses of "anthropocentric" where we can sensibly speak of some descriptions being more anthropocentric than others. A physiological description of an epileptic fit is different than an ordinary description of such a fit (say, Dostoevski's descriptions). But in both cases to understand the descriptions we would have, to some extent at least, to understand the purposes and interests relevant to devising such descriptions. Only as beings with purposes and interests could we understand the talk. This is as true of humanoid beings as of us. If we come to understand each other we must also have some shared purposes and interests. Indeed there is no common understanding without it. For Williams's absolute conception to do the philosophical work he wants it to do it must show us that by going to what he regards as the less anthropocentric description we "get closer to reality," just as many assume that the physiological description of the epileptic fit is more accurate than the phenomenological one. But the Putnam-Rorty point au contraire is that it is just different and made with different ends in view. We have no understanding of what "getting closer to reality" could come to taken as a perfectly general, contextless claim. I discuss distorted and undistorted discourse in my "Undistorted Discourse, Ethnicity, and the Problem of Self-Definition," Ethnicity and Language, ed. Winston A. Van Horne (Madison, Wisconsin: University of Wisconsin System, 1987), 15-36, my "Legitimation and Ideology," Ratio XXIX, no. 2 (December 1987), pp. 111-121, and in my "Legitima- 
The constraint to relevant interests and purposes is to acknowledge that there is no adopting or seeing a perspective to be more adequate without reference to interests and purposes. Perspectives do not just stand there, apart from such considerations, as somehow more or less adequate in themselves. If we want to do social anthropology such and such a conception and characterization of kinship is the more adequate. ${ }^{6}$ But the claim itself, though not the interest, must, to be acceptable, be sustained by the force of the better argument or the more adequate deliberation. Moreover, even someone who is not at all interested in social anthropology or kinship classification - it is not a part of her repertoire of purposes - could come to recognize, examining the soundness of the arguments or the perspicuity of the deliberations involved, that, if she were interested in kinship classification, this is the most undistorted perspective available at the time and for the foreseeable future. And to say that is all that we can reasonably claim. Articulators of distinctions between distorted and undistorted discourse should not try for the impossible and to rationalistically attempt to transcend fallibilism. There is no such transcendental perspective. But again, depending on the purposes involved, the undistorted perspective or the less distorted perspective may be either a narrower or a wider

tion in Complex Societies: Some Habermasian Themes", Annals of Scholarship 7, no. 1 (1990), 51-89.

${ }^{6}$ But for other purposes other characterizations, including sometimes ordinary ones, are the more adequate. There is no just saying what is the most adequate characterization sans phrase. That is always a contextual, purpose-dependent, interest-relative matter. Forgetting this gives rise to the incoherent, but pervasively assumed - though often rather unconsciously- belief that some descriptions are "just closer to reality" than others. The trick is to recognize the incoherence of this without being led to thoughts of relativism. See Alan Garfinkel, Forms of Explanation (New Haven, Connecticut: Yale University Press, 1981). 
perspective, though it is also true that not infrequently in social and moral deliberations the wider perspective, if it is also the less undistorted perspective, is something to be devoutly sought. ${ }^{7}$

If, as I have argued, an absolute conception of the world is incoherent, then there can be no discourse which is less, or for that matter more, anthropocentric than another. ${ }^{8}$

7 Descriptions can be more or less localized and some are more ethnocentric than others and some may not be ethnocentric at all. But since (pace Williams) an absolute conception of the world is incoherent, descriptions cannot be more or less anthropocentric as they can be more or less localized or more or less ethnocentric, for, in the relevant sense, there is nothing in the way of a coherent conception of a nonanthropocentric perspective or description to make a construct with an anthropocentric one. "Anthropocentric description" is pleonastic and makes no nonvacuous contrast with some other kind of description. Richard Rorty well claims against Charles Taylor that "it is not clear how, unless you can manage to believe in a transcendent yet concerned deity, you are supposed to avoid anthropocentrism." Richard Rorty, "In a Flattened World," London Review of Books, 15, no. 7 (April 8, 1993), 3. Moreover, though talk of a transcendent deity is more familiar, it is no more coherent than talk of an absolute conception of the world. I argue this, and do not merely assert it, in, among other places, my Philosophy and Atheism (Buffalo, New York: Prometheus Books, 1985).

8 This would be wrong and part of what Williams claims would be vindicated, if we were to construe "anthropocentric" narrowly to just mean centered around human concerns; but if instead we allow "anthropocentric" to range as well over humanoid beings (if such there be) with a language, intentions, sensations, feelings, purposes, desires, etc. - the repertoire that Wittgenstein and Davidson attach to such beings - then there is no coherent alternative to an anthropocentric perspective. But that is a) the relevant sense of "anthropocentric" here and $b$ ) we neither want to even try to rule out a priori that we might be able, with some hard and imaginative work, to come to communicate with humanoid but still non-human beings from (say) other planets, nor claim that when we consider the possibilities of life on other planets that we could reasonably claim that only human beings could have such a repertoire. It is not unlikely that there are such humanoid beings and that we might even eventually be able, after we come in contact with them and stay in contact for sometime, to talk 
There is no way of just describing the world as it is in itself or saying what it would be like in order to give the one uniquely true description of the world, a description which could be utilized by any observer, even a non-human one, in describing and, with that description, understanding, what the world is like in itself quite apart from any perspective or any cluster of interests. Without the possibility of an "absolute conception of the world" but with instead it being the case that the very way we describe, and the very terms of our descriptions, are in important ways dependent on our interests and purposes, there can be no non-anthropocentric descriptions. Thus one discourse (pace Williams) cannot be less, or indeed more, anthropocentric than another. But one discourse can be less localized or less ethnocentric than another, if it is less entrapped in particular, and not infrequently blinkered, culturally peculiar conceptions. By this I have in mind things like some people, forgetting about small-scale societies, claiming that

together and become conversational partners: something we cannot do with animals. At least philosophers should not get in the business of trying to rule such things out a priori. However, if a) is denied, and if welltakenly so, then we have between Putnam-Rorty, on the one hand, and Williams, on the other, the usual philosophical pseudo-conflict so well described by John Wisdom. If, quite literally (following dictionaries), we take "anthropocentric" simply to mean "centering on human beings" and "taking them to be the central fact of the universe, to which all surrounding facts have reference," then there can, of course, be "non-anthropocentric descriptions" as well as "anthropocentric descriptions," but if, as is relevant to our present discussion, "anthropocentric descriptions" and "anthropocentric perspectives" are taken to be descriptions or perspectives which depend for their intelligibility on their requiring some distinctive human or humanoid interests or purposes, then there can be no non-anthropocentric descriptions or perspectives. Even the person (say, a "deep" ecologist) who does not wish to give human interests pride of place against other interests (say, those of dogs, deer or chimps), still, with his interests and purposes, must articulate that conception. It is expressive of those very interests of his. It is not something which could just be there apart from them. 
all democracies must be representative democracies or, forgetting about other perhaps feasible possibilities, claiming that all democracies or (implicitly utilizing a persuasive definition) all "real democracies" must be capitalist democracies. ${ }^{9}$

Less localized ways of viewing things are ways of viewing things that are less culturally or historically peculiar or less a matter of the distinctive beliefs of a particular historically and culturally situated class, gender, ethnic group, or race. Localized beliefs become ethnocentric when they are not only localized but, as well, when localized beliefs are taken by the people who have them as more than localized ways of construing things. That is to say, although they are local and recognized to be so, they are also, the ethnocentric claim goes, the plainly correct or true way of viewing things for everyone or at least everyone capable of superior rationality or insight. Perhaps none of us can escape some degree of ethnocentricity, but that notwithstanding, ethnocentricity plainly admits of degrees, and, moreover, not everyone need believe that his tribal mores, his historically and culturally situated beliefs, are the truth and the way. We are not that much in the dark about others - Montaigne was wiser here than Descartes - and under fortunate circumstances they can become our conversational partners. With no absolute conception, there is no such thing as "the truth and the way," but in escaping (partially escaping) ethnocentricity we gain a measure of objectivity. Being, and inescapably, aboard Neurath's ship we do not suffer from conceptual imprisonment. We continually rebuild the ship at sea.

Recibido: 24 de junio de 1993

9 On the non-necessity of "real democracies" or "genuine democracies" being capitalist democracies, see Joshua Cohen and Joel Rogers, On Democracy (Harmondsworth, England: Penguin, 1983). 


\section{RESUMEN}

La concepción absoluta del mundo consiste en una explicación del mundo que sería independiente en grado sumo de las peculiaridades humanas. Es una despcripción ideal que podría usar cualquier observador incluso un ser no humano, capaz de investigar el mundo. Bernard Williams formuló esta concepción para derrotar todas las formas de perspectivismo, relativismo y antropocentrismo sin quedar en obligación con el realismo metafísico. Para cumplir con esto, la concepción está diseñada de tal modo que proporcione un contraste inteligible entre el mundo como es en sí mismo y el mundo como nos parece que es. Hilary Putnam y Richard Rorty han sostenido que semejante concepción del mundo es incoherente. No tenemos, ni podemos tener, ninguna concepción de la descripción del mundo única, singularmente verdadera. Williams intenta refutar esto, pero se alega que la respuesta de William a sus críticos no es válida. Sin embargo, también se argumenta que lo inevitable del perspectivismo no implica etnocentrismo ni parroquialismo, así como tampoco un rechazo de la distinción habermasiana entre discurso distorsionado y no distorsionado.

[Traducción de Gabriela Montes de Oca V.] 